\title{
Cysteine Proteinases and Cystatins
}

\author{
Adeliana S. Oliveira ${ }^{1}$, José Xavier-Filho ${ }^{2}$ and Maurício P. Sales ${ }^{1 *}$ \\ ${ }^{I}$ Laboratorio de Química e Função de Proteinas - LQFP; Departamento de Bioquímica; Universidade Federal do \\ Rio Grande do Norte; Natal - RN - Brazil. ${ }^{2}$ Universidade Estadual do Norte Fluminense; Centro de Biociências e \\ Biotecnologia; Laboratorio de Química e Função de Proteinas e Peptídeos; msales@cb.ufrn.br; Campos dos \\ Goytacazes - RJ - Brazil
}

\begin{abstract}
This review describeds the definition, localization, functions and examples of cysteine proteinases and their protein inhibitors in vertebrate, non-vertebrate animals and plants. These inhibitors are related with defense mechanisms of plant against pests. It also describes the factors involved in the specific cysteine proteinase-cystatin interaction and high degree of affinity and large specificity in this interaction which are not only represented by the compatibility between amino acid residues of the active site involved in catalysis, but also of all amino acid residues that participante in the enzyme-inhibitor interaction.
\end{abstract}

Key words: Cysteine proteinases, Cystatin, Phytocystatins

\section{INTRODUCTION}

Enzymes constitute a specialized and diverse group of proteins that have several roles in many physiological processes. Proteolytic enzymes such as proteinases which are involved in digestive processes, proenzymes activation, liberation of physiologically active peptides, complement activation, inflammation processes and others are part of this protein group (Neurath, 1984). Proteinases are grouped into four categories according to the essential amino acid residue at their active sites, the optimum $\mathrm{pH}$ range of activity, amino acid sequences similarities, similarity to inhibitors. Proteinases are classified as serine-, cysteine-, aspartic and metalloproteinases (Bode and Huber 1992). Examples of these have been identified in plants, insects, microorganisms and are all like to those found in mammalian (Table 1).
Inhibitor proteins have been found for each of the four mechanistic classes of proteinases and a large number of proteinases inhibitors are directed towards serine- and cysteine proteinases (Barrett et al., 1986; Turk and Bode, 1991). In contrast, only a few of those inhibitors are known for asparticand metalo-proteinases (Ryan, 1990; Jouanin et al., 1998). Studies on plant protein inhibitors are important due their involvement in defense mechanism and in protection of seeds reserves from premature hydrolysis (Ryan, 1989, 1990; Domoney et al., 1993). This review describes the relationship between cysteine proteinases of insects and cysteine proteinase inhibitors of plants.

\section{CYSTEINE PROTEINASES}

In vertebrate, the cysteine proteinases are involved in lysosomal protein degradation systems but also play a extracellular role such in some metabolic

\footnotetext{
*Author for correspondence
} 
disorders (Trysellius and Hultmark, 1997). In nonvertebrate such as nematodes and mite, cysteine proteinases are among the digestive enzymes (Rawlingsand Barrett, 1994; Pernas et al., 1998). In arthropods such as lobsters, they play a digestive role, but are also related in the nervous system (Rawlings and Barrett, 1994; Le Boulay et al.,1995). In insects, they are utilized in the digestive processes (Rawlings and Barrett, 1994) but are found in several other tissues, indicating that they may also play other roles (Yamamoto et al. 1994; Matsumoto et al., 1995, 1997). Studies on the $\mathrm{pH}$ dependence of cysteine proteinase activity in crude extract of insect larvae have indicated that activity was generally in the alkaline pH range (Bode and Huber, 1992), which was the optima $\mathrm{pH}$ of the cysteine proteinases activities.(Ryan,1990).

Table 1 - Group of proteinases

\begin{tabular}{|c|c|c|c|}
\hline PROTEINASES & $\begin{array}{l}\text { AMINO ACID } \\
\text { IN ACTIVE SITE }\end{array}$ & $\begin{array}{l}\text { pH OPTIMUM } \\
\text { (RANGE) }\end{array}$ & PROTEINS \\
\hline Serine proteinase & Ser; His & $7-9$ & Trypsin, Chymotrypsin, Elastase, Cathepsin(+) G \\
\hline Cysteine proteinase & Cys & $4-7$ & $\begin{array}{l}\text { Papain*, Ficin, Bromelain, Ananain, Cathepsins }(+) \text { B, C, H, K, } \\
\text { L, O, S and W }\end{array}$ \\
\hline Aspartic proteinase & (2) Asp, Try & below 5 & Cathepsin $(+)$ D and E, Renin, Pepsin \\
\hline Metallo-proteinase & Metal ion & $7-9$ & Carboxipeptidases A and B, aminopeptidases \\
\hline
\end{tabular}

* Papain isolated from the latex and fruit of Carica papaya have been used to identify cysteine proteinase inhibitor of the plant origin; (+) The term "Cathepsin" is generally used for the lysosomal cysteine protease (Cygler and Morb, 1997; Matsumoto et al., 1997).

Table 2 - Cysteine proteinases from insects

\begin{tabular}{|c|c|c|c|c|}
\hline INSECT SPECIES & ORDER & $\mathrm{D} / \mathrm{ND}$ & ENZYME TYPE & REFERENCE \\
\hline Sitophilus zeamais & Coleopteran & $\mathrm{D}$ & Cathepsin L & Matsumoto et al., 1997 \\
\hline \multirow[t]{3}{*}{ Sarcophaga peregrina } & Diptera & ND & Cathepsin L & Homma et al., 1994 \\
\hline & & ND & Cathepsin B & Takahashi et al., 1993 \\
\hline & & ND & Bovine Trypsin-like & Nakajima et al., 1997 \\
\hline \multirow[t]{2}{*}{ Leptinotarsa decemlineata } & Coleoptera & $\mathrm{D}$ & Cathepsin L & Michaud et al., 1996 \\
\hline & Chrysomelidae & & Cathepsin B, H and D* & Thie and Houseman, $1990\left(^{*}\right)$ \\
\hline \multirow[t]{2}{*}{ Drosophila melanogaster } & Diptera & ND & Cathepsin L & Matsumoto et al., 1995 \\
\hline & & $\mathrm{D}$ & Cathepsin L & \\
\hline \multirow{2}{*}{$\begin{array}{l}\text { Manduca Sexta } \\
\text { (tabacco hornworm) }\end{array}$} & Lepidoptera & $\mathrm{D}$ & Trypsin-like & Schukle and Murdock, 1983 \\
\hline & Sphigidae & & & \\
\hline \multirow[t]{2}{*}{ Acanthoscelides obtectus } & Coleoptera & $\mathrm{D}$ & Cathepsin B & Wieman and Nielsen, 1988 \\
\hline & Bruchidae & & & \\
\hline \multirow[t]{2}{*}{ Rhodinius prolixus Stal } & Hemiptera & $\mathrm{D}$ & Cathepsin B & Houseman and Downe, 1982, 1983 \\
\hline & Reduviidae & $\mathrm{D}$ & Cathepsin D & \\
\hline \multirow{2}{*}{$\begin{array}{l}\text { Zabrotes subfasciatus } \\
\text { (mexican bean weevil) }\end{array}$} & Coleoptera & $\mathrm{D}$ & $\mathrm{CP}$ & Lemos et al., 1990 \\
\hline & Bruchidae & $\mathrm{D}$ & AP & \\
\hline \multirow{4}{*}{$\begin{array}{l}\text { Tribolium castaneum } \\
\text { (red flour beetle) }\end{array}$} & Coleoptera & $\mathrm{D}$ & Catepsin D & Blanco-Labra et al., 1996 \\
\hline & & $\mathrm{D}$ & Catepsin B & Murdock et al., 1987 \\
\hline & & $\mathrm{D}$ & SP & Birk et al., 1960 \\
\hline & & $\mathrm{D}$ & $\mathrm{CP}$ & Liang et al., 1991 \\
\hline \multirow{4}{*}{$\begin{array}{l}\text { Callosobruchus maculatus } \\
\text { (cowpea weevil) }\end{array}$} & Coleoptera & $\mathrm{D}$ & Cathepsin B & Gatehouse et al., 1985 \\
\hline & Bruchidae & $\mathrm{D}$ & AP & Kitch and Murdock, 1986 \\
\hline & & $\mathrm{D}$ & SP & Silva and Xavier-Filho, 1991 \\
\hline & & & & Xavier-Filho and Coelho, 1980 \\
\hline \multirow{2}{*}{$\begin{array}{l}\text { Spodoptera exigua } \\
\text { (beet army worm) }\end{array}$} & Lepidoptera & $\mathrm{D}$ & $\mathrm{CP}$ & Jongsma et al., 1995, 1996 \\
\hline & Noctuidae & $\mathrm{D}$ & $\mathrm{SP}$ & \\
\hline \multirow{2}{*}{$\begin{array}{l}\text { Mimosestes mimosae } \\
\text { (algaroba beetle) }\end{array}$} & Coleoptera & $\mathrm{D}$ & Trypsin-like & Pereira, 2000 \\
\hline & Bruchidae & $\mathrm{D}$ & $\mathrm{CP}, \mathrm{AP}$ & \\
\hline
\end{tabular}

$\mathrm{D}$, digestive enzymes; ND, non-digestive enzymes; $\mathrm{CP}$, cysteine proteinase; $\mathrm{AP}$, aspartic proteinase; SP, cysteine proteinase with similarity no related. 
Experiments made with insect larvae showed that insects as well as some animals used a mixture of digestive enzymes to hydrolyze ingested proteins (Applebaum, 1985). The type of mixture could be the result of the type of ingested food (Ryan, 1990; Blanco-Labra et al., 1996) (Table 2).

Plant cysteine proteinases are found particularly in the vacuoles and are responsible for the mobilization of endosperm storage proteins during seeds germination. This provides nitrogenous nutrients to support the growth of young seedlings. Cysteine proteinases are also found in the extracellular midium such as those from papaya and fig (Rawlings and Barrett, 1994) (Table 3).

The cysteine proteinases require processing such as removal of the amino-terminal fragment to produce the active enzyme. The amino-terminal region, also called proregion, plays important roles not only as inhibitors of enzymatic activity but for the correct folding of the newly synthesized protein and to protect it against denaturing effects in sudden changes in the $\mathrm{pH}$ conditions. In terms of the proregion, Cathepsin L-like and Cathepsin B-like enzymes are subfamilies of the papain family.

Table 3 - Plant cysteine proteinases

\begin{tabular}{cc}
\hline SOURCES & SIMILARITY AND REFERENCE \\
\hline Oryzains $\alpha$ and $\beta$ & Papain \\
Oryzain $\gamma$ & Cathepsin H \\
(Rice seeds) & (Abe et al., 1991) \\
Aleurains (barley) & Cathepsin H \\
EP-C1 & (Mikkonen et al., 1996) \\
Cathepsin L \\
(Phaseolus vulgaris) & (Tanaka et al., 1993) \\
EP-B (barley) & Cathepsin L \\
SH-EP & (Koehler et al., 1990) \\
Cathepsin L \\
(Vigna unguiculata) & (Mitsuhashi et al., 1986) \\
\hline
\end{tabular}

Table 4 - Alignment of the aminoacid sequences of the several cysteine proteinases

\begin{tabular}{|c|c|c|}
\hline \multirow[t]{2}{*}{$\mathrm{Pp}$} & ExxxRxxxFxxNxxxIxxxN & $(-)$ \\
\hline & Karrer et al., 1993 & \\
\hline \multirow[t]{2}{*}{$\mathrm{Vm}$} & ExxxRxxxFxxNxxxVxxxN & $(-)$ \\
\hline & Karrer et al., 1993 & \\
\hline \multirow{2}{*}{$O-\alpha$} & ExxxRxxxFxxNxxxIxxxN & $57-75$ aa residues \\
\hline & Watanabe et al., 1991 & \\
\hline \multirow[t]{2}{*}{$\mathrm{O}-\beta$} & ExxxRxxxFxxNxxxVxxxN & $69-88$ aa residues \\
\hline & Watanabe et al., 1991 & \\
\hline \multirow[t]{2}{*}{ EPB-1 } & ExxxRxxxFxxNxxxIxxxN & $51-70$ aa residues \\
\hline & Mikkonen et al., 1996 & \\
\hline \multirow[t]{2}{*}{ EPB-2 } & ExxxRxxxFxxNxxxIxxxN & 51-70 aa residues \\
\hline & Mikkonen et al., 1996 & \\
\hline \multirow[t]{2}{*}{ SzL } & ExxxRxxxFxxNxxxVxxxS & 43-62 aa residues \\
\hline & Matsumoto et al., 1997 & \\
\hline \multirow[t]{2}{*}{$\mathrm{mcL}$} & ExxxRxxxWxxNxxxIxxxN & $(-)$ \\
\hline & Tryselius and Hultmark, 1997 & \\
\hline \multirow[t]{2}{*}{$\mathrm{mcK}$} & DxxxRxxxWxxNxxxIxxxN & $(-)$ \\
\hline & Tryselius and Hultmark, 1997 & \\
\hline
\end{tabular}

Pp (papaya papain); Vm (Vigna mungo); O- $\alpha$ and O- $\beta$ (cysteine proteinases of the rice seeds, orizains); EPB-1 and EPB-2 (cystine proteinases of the barley seeds); SzL (Cathepsin L-like digestive cysteine proteinases of the Sitophilus zeamais); mcL and mcK (mammalian Cathepsins L, K,) and (-) data not found.

They form two group distinct of enzymes: the proregion of Cathepsin B is significantly shorter ( $\sim 60$ amino acid residues) than the proregion of Cathepsin L, with approximately 100 amino acid residues. In three-dimensional structures of members of the papain family two distinct domains are commonly observed, the aminoterminal domain is mostly $\alpha$-helical while the 
carboxyl-terminal domain contains predominantly $\beta$-sheets. The active site consists of Cys 25 and His 159 (papain numbering) and is supplemented by Asn 175 hydrogen bonded to His 159, and Gln 19. Active site of the Cathepsin B differ of others Cathepsin due to the presence of the so-called occluding loop, which can be responsible for the exopeptidase activity this protein. Several members of the papain family show preferences for bulky hydrophobic residues occupying the S2 subsite due to the presence of the Ser 205 residue in this subsite, whereas Cathepsin B prefers arginine (Karrer et al., 1993). In the papain family enzymes with different activities are found, including endopeptidases (such as papain and Cathepsins B, H, L and C), aminopeptidase (Cathepsin $\mathrm{H}$ and $\mathrm{C}$ ) and carboxipeptedase activity (Cathepsin C). There are also differences in the proteolytic activities of the Cathepsins in relationship to $\mathrm{pI}$ value and $\mathrm{pH}$ optimum: the Cathepsin B (pI = 4.5 - 5.5; pH 6.0), Cathepsin H $(\mathrm{pI}=6.0$ - 7.1; $\mathrm{pH} 6.8)$ and Cathepsin L $(\mathrm{pI}=5.5-$ 6.1; pH 5.5) (Rawlings and Barrett, 1994; Cygler and Morb,1997; Turk et al.1997).

Karrer et al. (1993) observed that all the cysteine proteinases had similarities to mammalian $\mathrm{H}$ and $\mathrm{L}$ Cathepsins containing the ERFNIN sequence, (e.g. ExxxRxxxFxxNxxxIxxxN; where $\mathrm{x}$ represented amino acid variants). However, Cathepsin B-like protein lacks or contains only part of this sequence, as result of the shorter proregions of the Cathepsin B-like protein (Table 4). These autores also suggest that ERFNIN sequence serves to inhibit protein activity and that its removal convert the protein to the enzymatically active form (Table5).

Table 5 - The alignment of the sequences of the proregions of mammalian Cathepsins L and B

\begin{tabular}{ll}
\hline $\mathrm{mcL}$ & $\ldots$ MNEEGWRRAVWEKNMKMIELHNQEYR \\
& (amino acids:..25-50..) \\
$\mathrm{mcB}$ & HDKPSFHPLSDDM I NY I NKQN \\
& (amino acids: $1-21 \ldots . .$. ) \\
\hline
\end{tabular}

Difference exist between the two protein sequences (ERFNIN) and short pro-region of Cathepsin B in comparison with that of the Cathepsin L. The data were on references of Cygle and Morb, 1997; Trysellius and Hultmark, 1997.

\section{CYSTATINS}

The term cystatin refers to proteins that specifically inhibit the activity of papain and related cysteine proteinases (Cathepsin $\mathrm{B}, \mathrm{H}$ and $\mathrm{L}$, ficin, Bromelain). Their presence in microorganism, animal and plant species may be ubiquitous. These proteins are all related by structure and function to an inhibitor of cysteine proteinase, which was first described in egg white and was later called chicken egg white cystatin (Colella et al., 1989). Cystatins have been found to be evolutionarily related, forming the "cystatin superfamily". Members of the superfamily may be divided into three groups (or families) of proteins more closely related which comprise the animal cystatins (Barrett et al., 1986; Barrett, 1987) and one family from plant cystatins. The classification in families is based on primary sequence similarities, molecular masses, number of disulfide bonds and subcellular localization. Others families are suggested with bases in these aspects.

\section{FOUR FAMILIES OF CYSTATINS}

Family-1 cystatins, commonly known as stefins family, contain no disulfide bonds or carbohydrate groups with molecular mass of around $11 \mathrm{kDa}$, the molecules consist of about 100 amino acid residues and are cytosolic proteinas (Machleidt et al., 1983; Sato et al., 1990).

Family-2 cystatin, or only cystatin family, are proteins that contain two intra-chain disulfide bonds near the carboxyl-terminus, are glycosylated with molecular mass about 13-24 $\mathrm{kDa}$ with approximately 115 amino acid residues. Family-2 cystatins are known to be secreted and contain a signal sequence (Abranhanson et al., 1987).

Family-3 cystatin or Kininogen family, comprise the blood plasm kininogens which are larger than the members of the two other families and are the most complex cystatin molecules with high molecular mass $(60-120 \mathrm{kDa})$. These proteins are known to have domains in tandem that resulted from two duplications of genetic material of family-2 cystatins. Their composite sequences comprising about 355 amino acid residues that contain the bradykinin moiety, with additional 
dissulfide bonds, are glycosylated molecules and are also secreted proteins. The Kininogens play an important role in blood coagulation process (Salvesen et al., 1986). Some family-2 and family3 cystatins were reported to exhibit sequence homology with the active sitesequence of Bowman-Birk type-trypsin inhibitor (Saitoh et al., 1991). Other cysteine proteinase inhibitors have their primary structure similar to those of the Kunitz-type soybean trypsin inhibitor family (Brzin et al., 1988). All the cystatins of which the primary structure have so far been elucidated contain the pentapeptide Gln-Val-Val-Ala-Gly (in most falimy-1 and -3 cystatins) and homologous sequences (e.g. Gln-X-Val-Y-Gly) are found in other cysteine proteinase inhibitors in family-2 cystatins (Barrett et al., 1986). The sequences, Phe-Ala-Val, localized near the carboxyl-terminus and the dipeptide Phe-Try, near the aminoterminal are conserved among family-2 but generally are absent in family-1 and family-3 cystatins. It has been speculated that this pentapeptide and dipeptide regions could be important for the binding to cysteine proteinase (Machleidt et al., 1989; Turk et al., 1997).

Family-4 cystatin, the phytocystatins (Turk and Bode, 1991; Turk et al., 1997), including almost all plant cysteine proteinase inhibitors. This family of proteins are known to have characteristics that are found commonly in most family- 1 and -2 cystatins. Among plant cystatins, the oryzacystain from rice seeds was the first inhibitor of plant origin considered one member of the cystatin superfamily that is related by structure and function to ckicken egg white cystatin (Barrett et al., 1986). Cysteine proteinase inhibitors of the plant origin can be classified in two groups, one constituted by phytocystatins which possess single domain, comprised the majority of the phytocystatins (Abe et al., 1987a,b; Pernas et al., 1998) and the second only possess multiple domains, for example, multicystatin isolated from potato tubers (Walsh and Strickland, 1993) and cystatin of the tomato leaves (Bolter, 1993). Some researches showed that phytocystatins are inhibitory proteins that show non-competitive type inhibition Kinetic towards papain. These are corn cystatin I and oryzacystatin-I (Abe et al., 1994), soybean, L1 and R1 (Zhao et al., 1996), chestnut seed cystatin (Pernas et al., 1998), Prosopis juliflora seeds (Oliveira., 2000). Although, Barrett (1987) has related that cystatins are reversible and competitive inhibitors of papain (Figure 1).

Phytocystatins have been identified in a variety of higher plants in both monocot and dicot species, such as rice (Abe et al., 1987a,b), maize (Abe et al., 1992), soybean (Hines et al., 1991; Botella et al., 1996), Wisteria (Hirashiki et al., 1990;), potato (Gruden et al., 1997 ), seedlings from sorghum (Li et al., 1996), leaves of the Dianthus caryophyllus (Kim et al., 1999), and apple fruit (Ryan et al., 1998). The molecular mass of the phytocystatins purified showed a range between 5 to approximately $87 \mathrm{kDa}$ and stability to temperature and $\mathrm{pH}$ extreme ( Abe et al., 1987a,b, 1992; Oliva et al., 1987; Abe and Whitaker, 1988; Pernas et al., 1998). The Table 6 shows several phytocystatins

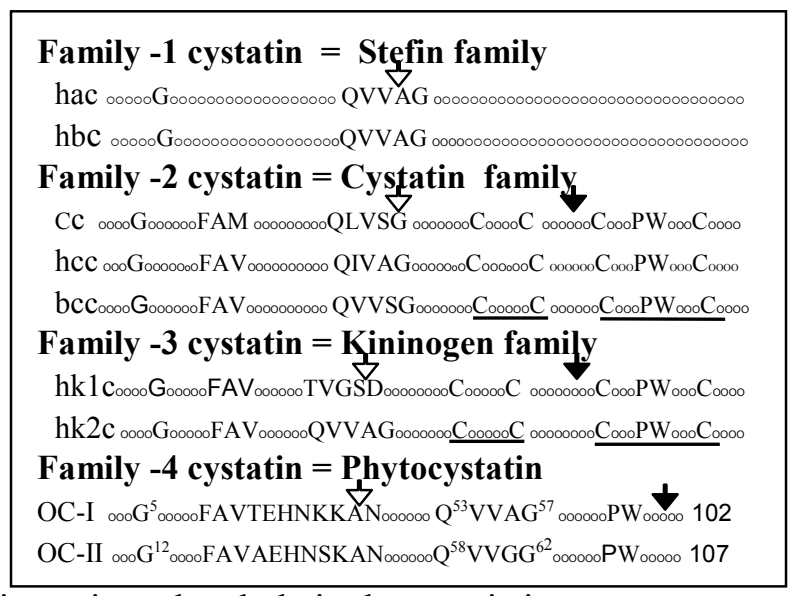

investigated and their characteristics.

Figure 1 - An alignment of the amino acid sequences of the four cystatin family. The sequences are those of human cystatin A (hac), human cystatin B (hab), chicken cystatin (cc), human cystatin C (hcc), beef colostrum cystatin (bcc); human Kininogen segment 1 (hk1c) and segment 2 (hk2c), oryzacistatin-I (OC-I) and oryzacystatin-II (OC-II). Positions of disulfite bonds in black line and the white dart and black dart indicated of the first and second intron position. The data are based on reference Barrett, 1987; Kondo et al., 1991; Mikkonen et al., 1996.

Oryzacystatin was the first well characterized plant cystatin, which could be classified as member of the family- 1 and -2 cystatins. The characteristics common between oryzacystatin and the family-1 cystatins comprise: absence of the disulfide bond, pentapeptide constituted by GlnVal-Val-Ala-Gly (residues 57-61) and molecular mass of approximately $11.5 \mathrm{kDa}$ with 102 amino 
acid residue. The comparison of the amino acid sequence of oryzacystatins showed approximately $30 \%$ identity with the family- 2 cystatins and the presence of the regions constituted by Phe-Ala-Val (residues 29-31) and Phe-Try (residues 83-84), suggesting that it could be classified as a member this family (Abe et al., 1987 a, b; Abe and Arai, 1991; Arai et al., 1991). Not all cysteine proteinases inhibitors show sequence homology.

Several cystatin have been isolated and sequenced, and some showed homology with serine proteinase inhibitor differeing also in their effectiveness of inhibition of various cysteine proteinases (Brzin et al., 1988; Ishikawa et al., 1994). In potato tubers was found family of cysteine proteinase inhibitor, which represented a distinct group of proteins that could be belong to Kunitz-type soybean trypsin inhibitor family. They did not possess the conserved region (Gln-X-Val-Y-Gly) that usually characterized the cystatin superfamily (Stubbs et al., 1990; Hatano et al., 1996, 1998). Bromelain inhibitor isoform isolated from pineapple stem by Lenarcic et al. (1992) showed to be a modest inhibitor for some cysteine proteinases including papain and bromelain. Their complete structure differed to those of other cystatins investigated due to the lack of the conserved region (Gln-X-Val-YGly) that was generally present in the majority of the cystatins. Recently, eight bromelain inhibitor isoforms were isolated and their primary structures were not similar to cystatin superfamily. These inhibitor exhibited structural similarity to the Bowman-Birk trypsin/chymotrypsin inhibitor from soybeans seeds. These facts suggested that proteinase inhibitors might have a common ancestor (Hatano et al., 1996, 1998).

Table 6 - Phytocystatins investigated and their characteristics.

\begin{tabular}{|c|c|c|c|c|}
\hline SOURCE and REFERENCE & $\mathrm{N}$ & N. aa. & M.m. (kDa) & $\mathrm{pI}$ \\
\hline Helianthus annus & Sca & 83 & $\sim 9$ & 5.6 \\
\hline Kouzuma et al., 1996 & Scb & 101 & $\sim 11$ & 9.6 \\
\hline $\begin{array}{l}\text { Persea americana } \\
\text { Kimura et al., } 1995\end{array}$ & $(-)$ & 100 & $\sim 11$ & $(-)$ \\
\hline $\begin{array}{l}\text { Daucus carrot } \\
\text { Ojima et al., } 1997\end{array}$ & EIP18 & 133 & 18 & $(-)$ \\
\hline $\begin{array}{l}\text { Oryza sativa } \\
\text { Abe et al., 1987a,b }\end{array}$ & OC-I & 102 & $\sim 12$ & 5.3 \\
\hline $\begin{array}{l}\text { Vigna unguiculata } \\
\text { Fernandes et al., } 1993\end{array}$ & $(-)$ & 97 & 10.7 & $(-)$ \\
\hline $\begin{array}{l}\text { Solanum tuberosum } \\
\text { Waldron et al., } 1993\end{array}$ & PMC & 757 & $\sim 87$ & $(=)$ \\
\hline $\begin{array}{l}\text { (pineapple stem) } \\
\text { Lenarcic et al., } 1992\end{array}$ & $(-)$ & 52 & $\sim 5$ & $(-)$ \\
\hline $\begin{array}{l}\text { Glycine max } \\
\text { Misaka et al., } 1996\end{array}$ & $(-)$ & 245 & 26 & $(-)$ \\
\hline $\begin{array}{l}\text { corn seeds } \\
\text { Abe et al., } 1992\end{array}$ & $(-)$ & 135 & 18 & $(-)$ \\
\hline $\begin{array}{l}\text { Castanea sativa } \\
\text { Pernas et al., } 1998\end{array}$ & $\mathrm{CsC}$ & $(-)$ & 11.2 & 6.9 \\
\hline $\begin{array}{l}\text { Wisteria floribunda } \\
\text { Hirashiki et al., } 1990\end{array}$ & WCPI-3 & $(-)$ & $\sim 15.7$ & 5.7 \\
\hline $\begin{array}{l}\text { Prosopis juliflora } \\
\text { Oliveira, } 2000\end{array}$ & $\mathrm{PjC}$ & $(-)$ & $\sim 20.5$ & $(-)$ \\
\hline
\end{tabular}

N, nomination; N.aa, number of amino acids; M.m., molecular mass; (-), date non-found; (=), domain-dependent. The molecular mass calculated by SDS-PAGE and/or filtration gel.

Several interaction model between the cystatins and their target cysteine proteinases were proposed that suggested three regions of the interactions: Gly residue near the amino-terminal, Gln-Val-ValAla-Gly central region conserved, and second hairpin loop near the carboxyl-terminal region. The data results of the X-ray crystallography did not show the involvement functional of the disulfide bonds in the interaction (Barrett, 1987; Bode et al., 1988; Machleidt et al., 1983, 1989; Salmia et al., 1980; Stubbs et al., 1990). In order to determine which regions was responsible for the papain-inhibitory activity, Abe et al. (1988) and Arai et al. (1991) evaluated the effects of the wild 
oryzacystatin and oryzacystatin truncated forms against papain activity. They observed that the primary region of interaction of the oryzacystatin responsible for the papain-inhibitory activity was the Gln-Val-Val-Ala-gly sequence and Pro-Try region could act also as a co-factor in the interaction, but the possibility that some other regions also contributed to inhibitory activity still remained (Table 7).

\section{FUNCTIONS ATTRIBUTED PHYTOCYSTATINS}

TO

Various biological functions have been attributed for phytocystatins: (a) Physiological functions of regulation of the endogenous proteinases activities in seeds during seeds maturation; (b) Participation of the inhibitors as important element in defence against attack by insects and nematodes that generally contain cysteine proteinases in their guts; and (c) Others functions not defined.

\section{(a) REGULATION OF ENDOGENOUS PROTEINASES}

The phytocystatins participate in the control of endogenous cysteine proteinases during the maturation and germination of the seeds (Abe and Arai, 1991; Abe et al., 1992). Oryzacystatins are considered to be inhibitors of oryzains $\alpha, \beta$ and $\gamma$, cysteine proteinases that are produced during seed germination (Watanabe et al., 1991). Zeins and corn proteinases were inhibited by corn cystatin, which suggested the involvement of the inhibitor in endogen defence mechanism (Steller, 1995). A proteinase prepared from germinating carrot seeds was inhibited by phytocystatin, named EICC, purified from seeds of carrot (Ojima et al., 1997).

Two soybean cysteine proteinase inhibitors recombinants, named $\mathrm{L} 1$ and $\mathrm{R} 1$, were tested against plant cysteine proteinases from mungo bean cotyledons (Vicilin peptidohydrolase), and was observed that R1 had substantially more inhibitory activity than L1 (Botella et al., 1996). Phytocystatins and cysteine proteinases were also required to regulate the programmed cell death (PCD) (Solommon et al., 1999). This process is required for plant development and senescence. Plant programmed cell death or apoptosis has been implicated in several plant process such as xylogenesis (Cerós and Carbonell, 1993), some forms of senescence, in the pathogens attack response and stresses response (Greenberg, 1996; Lamb and Dixon, 1997). Recently cysteine proteinases was reported to regulate the expression of specific proteinase inhibitor genes in soybean cells (Groover et al., 1997) such as Sbcys, which was a specific soybean cysteine proteinase inhibitor (Abe et al., 1992).

The observations that endopeptidasec activity of the Vicilin peptidohydrolase (cysteine endopeptidase from Vigna radiata cotyledons) occur in protein body and cytosolic localization of an inhibitory activity, has led to suggest to function in the cytoplasm protection against incidental rupture of protein body (Baumgartner and Chrispeels, 1976).

Table 7 - Effects of the wild oryzacystatin and several oryzacystatin truncated forms against papain activity.

\begin{tabular}{lc}
\hline wOC-I (Wild oryzacystatin-I) & PPIA \\
\hline Lacking 21 amino-terminal and & PPIA \\
11 carboxyl-terminal amino acids & ACI \\
Lacking 38 amino-terminal and & DR-PPIA \\
35 carboxyl-terminal amino acids & MPIA \\
Substitution of Gln-Val-Val-Ala-Gly by Pro-Val-Val-Ala-Gly or Leu-Val-Val-Ala-Gly: & E-PPIA \\
Substitution of Gln-Val-Val-Ala-Gly by & \\
Gln-Val-Asp-Ala-Gly & \\
Substitution of Gln-Val-Val-Ala-Gly by & Wal-Gly-Ala-Gly \\
Wild oryzacystatin (wOC-I); PPIA, potent papain inhibitory activity; ACI, almost completely inactive; DR-, reduced drasticly; \\
MPIA, moderate papain inhibitory activity; E-PPIA, potent papain inhibitory activity equivalent to that of wOC-I. In boldface
\end{tabular}




\section{(b) PROTECTION AGAINST INSECTS AND NEMATODES}

Several members of the Coleopteran order are tuber-, seed-, root- and leaf-eating insect. The presence of cysteine proteinase in the gut of these insects to hydrolyze ingested proteins, have implicated phytocystatin as proteins involved in the exogenous defense mechanisms (Abe et al., 1992; Gillikin et al., 1992; Waldron et al., 1993; Gruden et al., 1997). In vitro and in vivo inhibition of digestive proteinases from Coleopteran pests are summarized here that support this function.

Studies have shown that cysteine proteinases isolated from insect larvae can be inhibited by both non-proteinaceous and proteinaceous cysteine proteinase inhibitors. The effects of in vitro inhibition on the proteinases present in the guts from Coleopteran pests have been reported. Detection of the digestive proteinases present in the gut crude extract from Acanthoscelides obtectus were inhibited by $0.1 \mathrm{mM}$ E-64 [a specific non-proteinaceous cysteine proteinase inhibitor from Aspergillus japonicus, Trans-epoxisuccinylleucylagmentine], 20.0mM IAA (Iodoacetic acid) and $10.0 \mathrm{mM}$ NEM (N-ethylmaleimide) and $92 \%$, $63 \%$ and about $7 \%$ inhibition of the cysteine proteinases present in the crude extract were obtained, respectively. The proteins partially purified from crude extract of these larvae were inhibited in 100, 100 and $20 \%$, respectively in the presence of the same inhibitors (Wieman and Nielsen, 1988). Inhibitory activity against digestive proteinases from $Z$. subfasciatus larvae were measured with $0.028 \mathrm{mM} \mathrm{E}-64,10 \mathrm{mM}$ NEM, 1.2mM IAA, $1.0 \mathrm{mM}$ DPT (dithiopyridine) and $0.075 \mathrm{mM}$ cystatin that demostrated $55 \%, 35$, 29,29 and $46 \%$ inhibition on crude extract midgut larvae, respectively. After partially purification of protein, the inhibition index obtained were 80,75 , 84,43 and 57\%, respectively (Lemos et al., 1990). Liang et al. (1991) analyzed the digestive cysteine proteinases present in the crude extract from Sitophilus oryzae and T. castaneum against E-64, PCMS (p-chloromercuriphenylsulfonic acid) and Antipain at $10^{-3} \mathrm{M}$ concentration that inhibited more than $95 \%$ from both crude extract. Luminal contents from $D$. virgifera were measured with the use of several inhibitors, which demonstrated that $0.02 \mathrm{mM}$ E-64, $1.0 \mathrm{mM}$ IAA and pCMB (pchloromercuribenzoic acid), $0.01 \mathrm{mM}$ cystatin and $1.0 \mathrm{mM} \mathrm{Cu}^{++}$inhibited 30, 43, 39, 69 and $79 \%$ of the luminal activities, respectively (Michaud et al., 1995). Orr et al. (1994) demonstrated maximal inhibition by E-64 to total activity in the gut extract from $D$. undencempuctata and $D$. virgifera with 75 and $92 \%$ inhibition, respectively. Michaud et al. (1996) observed inhibition of the cysteine proteinases present in the Otiorynchus sulcatus crude extract by E-64 estimated at about $60 \%$ maximal inhibition. After elution of the crude extract in affinity chromatography used to remotion of oryzacystatin-sensitive proteinases using the GST/OCI fusion protein (GTS, glutathione S-transferase gene fusion system with oryzacystatin-I) preadsorbed onto GSH-agarose beads, the inhibitory activity decreased by $30 \%$. The effects of the E-64 were available on crude extract from $L$. decemlineata and $O$. sulcatus. In order to determine the inhibitory activity $100 \mu \mathrm{M}$ E-64 was used to acquisition of 87 and $62 \%$ inhibitions against proteinases of the both insects, respectively (Michaud et al., 1996). The cysteine proteinases present in the crude extract from D. virgifera were inhibited in $25 \%$ by $10^{-6} \mathrm{M}$ E-64 and $10^{-5} \mathrm{M}$ E-64 inhibit $80 \%$ of the digestive proteinases from $L$. decemlineata (Zhao et al., 1996). The effects of E-64 were also analyzed against $T$. castaneum and $L$. decemlineata when $1.5 \mu \mathrm{M}$ of E-64 inhibited more than $50 \%$ of the digestive proteinases from both insects (Pernas et al., 1998). Studies on inhibition caused by oryzacystatin on the activity of the $S$. oryzae and T. castanheum showed that $2 \times 10^{-5} \mathrm{M}$ oryzacystatin caused 88 and $90 \%$ inhibition of the digestive proteinases, respectively (Liang et al., 1991). The crude proteinases extract of $L$. decemlineata and $O$. sulcatus were inhibited in 45 and $35 \%$ respectively by oryzacystatin-I. After application of the crude proteinases extract in affinity chromatography (GSH-GST/OCI) used to remove the oryzacystatin-insensitive proteinases, the inhibition dramatically decreased (Michaud et al.,1996). Irie et al. (1996) demonstrated that intrinsic oryzacystatin (genetically untransformed) inhibited $20 \%$ of the cysteine proteinases from $S$. zeamais insects. However, corn cystatin prepared from transgenic rice plants inhibited approximately $95 \%$, when used in the same concentration. Orr et al. (1994) demonstrated the effects of PMC (multicystatin from potato tubers) on $D$. virgifera and $D$. undencempunctata. Digestive enzymes from $T$. castaneum were inhibited by $1 \mu \mathrm{M}$ of the cystatin purified from 
Castanea sativa seeds more than $50 \%$ inhibition, (Pernas et al., 1998). Recombinant soybean cystatin proteinase inhibitors, called L1, R1 and $\mathrm{N} 2$, showed substantial difference in inhibitory activities with about 10,20 and $40 \%$ inhibition, respectively, to $L$. decemlineata when used in concentration of $10^{-5} \mathrm{M}$. However, high inhibitory activities of the same proteins were observed to digestive proteinases from $D$. virgifera $(30,80$ and $80 \%$, respectively) used in concentrations of $10^{-6} \mathrm{M}$. These results suggested that the differential inhibitory activities or specificity of the inhibitors could be due to motifs or residues that differed in the proteic structures (Zhao et al., 1996).

The effects of proteinase inhibitors on the digestive physiology of insect is an important area of study and their results are attractive for the biological control of insect pests. Studies relating the effects of proteinase inhibitors on insect diets have been developed long time ago (Bolter and Jongsma, 1995). Recently, several studies have reported the consequences of the incorporation of proteinase inhibitors in diets of insect. These proteinase inhibitors, when present in the diet, resulted in an increased mortality rate, decreased weight gain, reduced fecundity and in some cases led the death (Wolfson and Murdock, 1987; Murdock et al., 1988; Campos et al., 1989; Bolter, 1993).

In vivo deleterious effects of E-64 and proteinaceous cysteine proteinase inhibitors (phytocystatins) on growth and development in Coleopteran have been reported by various authors. E-64, when ingest by larvae of the $L$. Decemlineata (Wolfson and Murdock, 1987), A. obtectus Say (Wieman and Nielsen, 1988; Chen et al., 1992), C. maculatus (Campos et al., 1989; Kuroda et al., 1996; Murdock et al., 1988) showed adverse physiological effects on these organisms. Chen et al. (1992) and Kuroda et al. (1996) demonstrated the effects of the Oryzacystatin when ingest by $C$. chinensis and $T$. castaneum, respectively. Incorporation of PMC in diet of $D$. virgiferaand $D$. undencempunctata demonstrated that multicystatin from potato tubers (PMC), which incorporated in concentration of 31.25 $\mu \mathrm{g} / \mathrm{cm}^{2}$ diet for first instar southern corn rootworm produced maximal inhibition growth of approximately $70 \%$, but increasing the concentration to $125 \mu \mathrm{g} / \mathrm{cm}^{2}$ had no additional effect, suggesting that the larvae had a population of proteolytic enzymes not sensitive to proteinaceous inhibitors that were able to generate sufficient amino acids to sustain limited growth (Orr et al., 1994). Recently Soyacystatin, cystatin from soybean, called soyacystatin $\mathrm{N}(\mathrm{scN})$ and $\mathrm{L}$ (scL), with $70 \%$ sequence identity, showed different insecticidal activities. The purified protein, $\mathrm{scN}$, substantially retarded growth of first and second instar larval of cowpea weevil, $C$. maculatus, by $0.2 \%$ of inhibitor in bioassay, while scL affected neither insect growth nor mortality (Koiwa et al., 1998). Oryzacystatin-I (OC-I, wildtype) and variant form, named OC-IdeltaD86 in which residue Asp86 was deleted, both expressed and regenerated from tomato hairy roots, showed detrimental effect on growth and development of Globodera pallida (plant parasitic nematode) (Urwin et al., 1995). Both oryzacystatins were also expressed and regenerated in Arabidopsis thaliana showed effect on the size and fecundity of Heterodera schachtii and Meloidogyne incognita females (Urwinetal,1997).

\section{(c) OTHER FUNCTIONS}

The effects of the proteinaceous cysteine proteinase inhibitors has also been tested in vitro against serine proteinases and Cathepsins $\mathrm{H}, \mathrm{B}$ and $\mathrm{L}$ too. Weak inhibitory effect from CSC was observed on trypsin and elastase (Pernas et al., 1998) and an cysteine proteinase inhibitory purified from cell cultures and seeds of carrot was weakly active against trypsin (Ojima et al., 1997). The results could be inferred to the fact that some family-2 and 3 cystatins exhibited some homology to the active site of the Bowman-Birk type-trypsin inhibitor (Saitoh et al., 1991; Watanabe et al., 1991), but homology was not found between proteins two classes.

Abe et al. (1991) observed that oryzains $\alpha$ and $\beta$ (papain-like enzymes) were preferentially inhibited by oryzacystatin-I (OC-I). However, oryzain $\gamma$, with similarity of cathepsin H-type, was natural target proteinase of the oryzacystatin-II (OC-II). On the other hand, Kondo et al. (1990) demonstrated that oryzacystatin-I (OC-I) showed significant inhibitory activity against papain and while oryzacystatin-II (OC-II) was more effective against cathepsin $\mathrm{H}$, neither OC-I nor OC-II showed any effective inhibition against cathepsin B or cathepsin L. 


\section{CONCLUSIONS}

The informations reviewed here showed that the interactions between cysteine enzymes and cysteine inhibitor are an integral part of plant defence. This fact has opened up new researches with fundamentaly and pratical aplications that could be used in plant breeding to produce modified plant with proteinaceous inhibitors, especialy with plant cystatins by DNA recombinant tecnology.

\section{RESUMO}

Nesta revisão foram descritas definições, localizações, funções e exemplos de proteinases cisteínicas e suas proteinas inibidoras em animais vertebrados e invertebrados e plantas. Tratamos principalmente com aqueles inibidores que são relatados com o mecanismo de defesa da planta contra pestes. Em adição, comentamos sobre recentes trabalhos que contribuíram para uma melhor compreenção dos fatores envolvidos na interação específica proteinase cisteínica-cistatina. Por outro lado, chamamos atenção para o alto grau de afinidade e grande especificidade na interação que não são apenas representadas pela compatibilidade entre os residuos de aminoácidos do sítio ativo envolvidos na catalise, mas também de todos os resíduos de aminoácidos que participam da interação enzima-inibidor.

\section{REFERENCES}

Abe, K.; Emori, Y.; Kondo, H.; Susuki, K. and Arai, S. (1987), Molecular cloning of a cysteine proteinase inhibitor of rice (oryzacystatin)-Homology with animal cystatins and transient expression in the ripening process of rice seeds. J. Biol. Chem., 262 : (35), 16793-16797.

Abe, M.; Kondo, H. and Arai, S. (1987), Purification and characterization of a rice cysteine proteinase inhibitor. Agric. Biol. Chem., 5,12763-2768.

Abe, K.; Emori, Y.; Kondo, H.; Arai, S. and Suzuki, K. (1988), The NH2- terminal 21 amino acid residues are not essential for the papain-inhibitory activity of oryzacystatin, a member of the cystatin superfamily. J. Biol Chem., 263 : (16), 7655-7659.

Abe, M. and Arai, S. (1991), Some properties of a cysteine proteinase inhibitors from corn endosperm. Agric. Biol. Chem., 55 : (9), 2417-2418.
Abe, M.; Abe, K.; Kudora, M. and Arai, S. (1992), Corn kernel cysteine proteinase inhibitor as novel cystatin superfamily member of plant origin. Eur. J. Biochem., 209, 933-937.

Abe, M.; Abe, K.; Iwabuchi, K.; Domoto, C. and Arai, S.(1994), Corn cystatin I expressed in Escherichia coli: investigation of its inhibitory profile and occurence in corn kernels. J. Biochem., 116 : (3), 488-492.

Abrahanson, M.; Ritonja. A.; Brown, M. A.; Grubb, A.; Machleidt, W. and Barrett, A. J. (1987), Identification of the probable inhibitory reactive sites of the cysteine proteinase inhibitors, human cystatin $\mathrm{C}$, and chicken cystatin. J. Biol. Chem., 262, 9688-9494.

Arai, S.; Watanabe, H.; Kondo, H.; Emori, Y. and Abe, K. (1991), Papain-inhibitory activity of oryzacystatin, a rice seed cysteine proteinase inhibitor, depends on the central Gln-Val-Val-AlaGly region conserved among cystatin superfamily members. Biochem., 109, 294-298.

Applebaum, S. W. (1985), Biochemistry of digestion. In: Kerkut, G. A and Gilbert, L. I. (eds.).Compehensive insect Physiology, Biochemistry and Pharmacology. Oxford : Pergamon Press. 4, 279311.

Baumgartner, B. and Chrispeels, M. J. (1976), Partial characterization of a protease Inhibitor which inhibits the major endopeptidase present in the cotyledons of mung-beans. Plant Physiol. 58, 1-6.

Baumgartner, B. and Chrispeels, M. J. (1977), Purification and characterization of Vicilin peptidohydrolase, the major endopeptidase in the cotyledons of mung-bean seedling. Eur. J. Biochem., 77, 223-233.

Barrett, A. J.; Rawlings, N. D.; Davies, E. M.; Macheleidt, M.; Salve-sen, G. and Turk, V. (1986), In: Barrett, A. J. and Sal-vesen, G. E. (eds.). Proteinase Inhibitors. Amsterdan : Science Publishers. 12, 515-569.

Barrett, A. J. (1987), The Cystatins; a new class of peptidase inhibitors. Trend Biochem. Sci., 12, 193-196.

Birk, Y. and Applebaum, Y. (1960), Effect of soybean trypsin inhibitors on the development and midgut proteolytic activity of Tribolium castaneum larvae. Enzymologia., 22, 318-326.

Blanco-Labra, A.; Martinez-Gallardo, N. A.; SandovalCarboso, L. and Delano-Frier, J. (1996), Purification and characterization of a digestive cathepsin Dproteinase isolated from Tribolium castaneum larvae (Herbst). Insect Biochem. Molec. Biol., 26: (1), 95-100.

Bode, W.; Engh, R.; Musil, D.; Thiele, U.; Huber, R.; Karshikov, A.; Brzin, J.; Kos, J. and Turk, V. (1988), The $2.0 \mathrm{~A}^{\mathrm{o}}$ X-ray crystal structure of chicken egg white cystatin and its possible mode of interaction with cysteine proteinase. The EMBO Journal.,7 : (8), 2593-2599. 
Bode, W. and Huber, R. (1992), Natural protein proteinase inhibitors and their interaction with proteinases. J. Biochem., 204, 433-451.

Bolter, C. J.(1993), Methyl Jasmonate induces papain inhibitor(s) in tomato leaves. Plant Physiol., 103, 1347-135.

Bolter, C. J. and Jongsma, M. A. (1995), Colorado potato beetles (Leptinotarsa decemlineata) adapt to proteinase inhibitors induced in potato leaves by methyl jasmonate. J. Insect Physiol., 41, 1071-1078.

Botella, M. A.; Xu, Y.; Prabha, T. N., Zhao, Y., Narasimhan, M. L., Wilson, K. A., Nielsen, S.S., Bressan, R .A. and Hasegawa, P.A.(1996), Differential expressio of soybean cysteine proteinase inhibitor genes during development and in response to wounding and methyl jasmonate. Plant Physiol., 112, 1201-1210.

Brzin, J.; Popovic, T.; Drobnic-Kosorok, M.; Kotnik, M. and Turk, V. (1988), Inhibitors of cysteine proteinases from potato. Biol. Chem. Hoppe Seyler., 369, 233-238.

Campos, F. A. P.; Xavier-Filho, J.; Silva, C. P.and Ary, M. B. (1989), Resolution and partial characterization of proteinases and $\alpha$-amylases from midguts of larvae of the bruchid beetle Callosobruchus maculatus (F). Comp Biochem. Physiol., 92 : (B), 51-57.

Cerós, M. and Carbonell, J. (1993), Purification and characterization of thiol-protease induced during senescence of unpollinated ovaries of Pisum sativum. Physiol Plant., 88267-274.

Chen, M. S.; Johnson, B.; Wen, L.; Muthukrishnan, S.; Kramer, K. J.; Morgan, T. D. and Reeck, G. R. (1992), Rice cystatin: bacterial expression, purification, cysteine proteinase inhibitory activity, and insect growth suppres-sing activity of a truncated form of the protein. Prot. Exp. Purif., 3, 41-49.

Colella, R.; Sakaguchi, Y.; Nagase, H. and Bird, J. W. C. (1989), Chiken egg white cystatin. J. Biol Chem., 264, 17164-17117.

Cygler, M. and Morb, J. S. (1997), Proregion structure of members of the papain superfamily. modeof inhibition of enzymatic activity. Biochem., 79, 645-652.

Domoney, C.; Welhan, I. and Sidebotton, C. (1993), Purification and characterization of Pisum seed trypsin Inhibitors. J. Exp. Bot., 44 : (261), 701-709.

Fernandes, K. V. S.; Sabelli, P. A.; Barratt, P.; Richardson, M.; Xavier-Filho, J. and Shewry, R. (1993), The resistence of cowpea seeds to bruchid beetle is not related to levels of cysteine proteinase inhibitors. Plant. Mol. Biol., 23, 215-219.

Gatehouse, A. M. R.; Butler, K. F.; Fenton, K. A. and Gatehouse, J. (1985), Presence and partical characterization of a major proteolytic enzyme in the larval gut of Callosobruchus maculatus. Entomol. Exp. Appl., 39279-86.
Gillikin, J. W.; Bevilacqua, S. and Graham, J. S. (1992), Partial characterization of digestive tract proteinases from western corn root-worm larvae, Diabrotica virgifera. Arch Insect Biochem. Physiol., 19, 285-298.

Groover, A.; DewilL, N.; Heidel, A. and Djones, A. (1997), Programmed cell death of plant tracheary elements differentiating in vitro. Protoplasma., 196, 197-211.

Greenberg, J. T. (1996), Programmed cell death: A way of life for plants. Proc. Natl. Acad. Sci., 93, 12094-12097.

Gruden, K.; Strukel, J. B.; Ravnikar, M.; PoljsakPrijately, M.; Mavric, I.; Brzin, J.; Pungercar, J. and Kregar, I. (1997), Potato cysteine proteinase inhibitor gene family: molecular cloning, characterization and immunocytochemica localisation studies. Plant Mol. Biol., 34, 317-323.

Hatano, K. I.; Kojima, M.; Tanokura, M. and Takahashi, K. (1996), Solution structure of bromelain inhibitor VI from pineapple stem: Structural similarity with Bowman Birk trypsin/chymotrypsin inhibitor from soybean. J. Biochem., 35, 5379-5384.

Hatano, K. I., Tanokura, M. and Takahashi, K. (1998), The amino acid sequences of isoforms of the bromelain inhibitor from pineapple stem. J. Biochem., 124, 457-461.

Hines, M. E.; Osuala, C. I. and Nielsen, S. S. (1991), Isolation and partial characterization of a soybean cystatin cysteine proteinase inhibitor of Coleopteran digestive proteolitic activity. J. Agric. Food. Chem., 39, 1515-1520.

Hirashiki, I.; Ogata, F.; Yoshida, N.; Makisumi, S. and Ito, A. (1990), Purification and complex formation analysis of a cysteine proteinase inhibitor (Cystatin) from seeds of Wisteria floribunda. J. Biochem., 108, 604-608.

Homma, K.; Kurata, S. and Natori, S. (1994), Purification, characterization, and cDNA cloning of procathepsin L from the culture medium of NIHSape-4, an embryonic cell line of Sarcophaga peregrina (flesh fly), and its involvement in the differentiation of imaginal discs. J. Biol. Chem., 269, 15258-15264.

Houseman, J. G. and Downe, A. E. R. (1982), Characterization an acidic proteinase from the posterior midgut of Rhodnius prolixus stal (Hemiptera:Reduviidae). Insect Biochem., 12 : (6), 651-655.

Houseman, J. G. and Downe, A. E. R. (1983), Cathepsin D-like activity in the posterior gut hemipteran insect. Comp. Biochem Physiol., 75 : (B), 509-512.

Irie, K.; Hosoyama, H.; Takeuchi, T.; Iwabuchi, K. and Watanabe, A. (1996), Transgenic rice established to express corn cystatin exhibits strong inhibitors activity against insect gut proteinases. Plant. Mol. Biol., 30, 149-157. 
Jongsma, M. A.; Bakker, P. L.; Peters, J.; Bosch, D. and Stiekema, W. J. (1995), Adaptation of Spodoptera exigua larvae to plant proteinase inhibitors by induction of gut proteinase activity insensitive to inhibition. Proc. Natl. Acad. Sci., 928041-8045.

Jongsma, M. A.; Peters, J.; Stiekema, W. J. and Bosch, D. (1996), Characterization and partial purification of gut proteinases of Spodoptera exigua Hübner (Lepidoptera:Noctuidae). Insect Biochem. Mol. Biol., 26, 623-632.

Jouanin, L.; Bonadé-Bottino, M.; Girard, C.; Morrot, G. and Giband, M. (1998), Transgenic plants for insert resistance. Plant Science., 131, 1-11.

Karrer, K. M.; Peifer, S. L. and Ditomas, M. E. (1993), Two distinct gene subfamilies within the family of cysteine protease genes. Proc. Natl. Acad. Sci., 90 3063-3067.

Kim, J. Y.; Chung, Y. S.; Paek, K. H.; Park, Y. I.; Kim, J. K.; Yu, S. N.; Oh, B. J. and Shin, J. S. (1999), Isolation and characterization of a cDNA encoding the cysteine proteinase inhibitor, induced upon flower maturation in carnation using supression subtractive hybridization. Mol. Cells., 9 : (4), 392-397.

Kimura, M.; Ikeda, T.; Fukumoto, D.; Yamasaki, N. and Yonekura, M. (1995), Primary structure of a cysteine proteinase inhibitor from the fruit of avocado (Persea americana Mill). Biosci Biotechnol Biochem., 59. (12), 2328-2329.

Kitch, L. W. and Murdock, L. L. (1986), Partial characterization of a major proteinase from larval of Callosobruchus maculatus (F.). Arc. Insect Biochem. Physiol., 3, 561-76.

Koehler, S. M. and Ho, T-HD. (1990), A major gibberellic acid-induced barley aleurone cysteine protease which digests hordein. Plant Physiol., 94, 251-258.

Koiwa, H.; Shade, R. E.; Zhu-Salzman, K.; Subramanian, L.; Murdock, L. L.; Nielsen, S. S.; Bressan, R. A. and Hasegawa, P. M. (1998), Phage display selection can differentiate insecticidal activity of soybean cystatins. Plant Journal., 14 : (3), 371-379.

Kondo, H.; Abe, K.; Emori, Y. and Arai, S. (1991), Gene organization of oryzacystatin-II, a new cystatin superfamily member of plant origin, is closely related to that of oryzacystatin-I but different from those of animal cystatins. FEBS. Lett., 278, 87-90.

Kondo, H.; Abe, K.; Nishimura, I.; Iwatanabe, H.; Emori, Y. and Arai, S. (1990), Two distinct cystatin species in rice seeds with different specificities against cysteine proteinases. J. Biol. Chem., 265 : (26), 15832-15837.

Kouzuma, Y.; Kawano, K.; Kimura, M.; Yamasaki, N.; Kadowaki, T.and Yamamoto, K. (1996), Purification, characterization, and sequencing of two cysteine proteinase L. inhibitors, Sca and Scb, from sunflower (Helianthus annus) seeds. J. Biochem., 6, 1106-1113.
Kuroda, M.; Ishimoto, M.; Suzuki, K.; Kondo, H.; Abe, K.; Kitamura, K. and Arai, S. (1996), Oryzacystatins exhibit growth-inhibitory and lethal effects on different species of bean insect pests Callosobruchus chinensis (Coleoptera) and Riptortus clavatus (Hemiptera). Biosci Biotechnol. Biochem., 60, 209212.

Lamb, C. and Dixon, R. A. (1997). The oxidative burst in plant dissease resistance. Annu. Ver. Plant Physiol. Plant Mol. Biol., 48, 251-275.

Le Boulay, C.; Van Wormhoudt, A. and Sellos, D. (1995), Molecular cloning and sequencing of two cDNAs encoding cathepsin L-related cysteine proteinases in the nervous system and in the stomach of the Norway lobster (Nephrops norvegi-cus). Comp Biochem. Physiol. 111 : (B), 353-359.

Lemos, F. J. A.; Campos, F. A. P.; Silva, C. P. and Xavier-Filho, J. (1990), Proteinases and amylases of larval midgut of Zabrotes subfasciatus eared on cowpea (Vigna unguiculata) seeds. Entomol. Exp. Appl., 56219-227.

Lenarcic, B.; Ritonja, A.; Turk, B.; Dolenc, I. D. and Turk, V. (1992), Characterization and structure of pineapple stem inhibitor of cysteine proteinase. Biol. Chem. Hoppe-Seyler, 373, 454-464.

Li, Z.; Sommer, A.; Dingermann, T. and Noe, C. R. (1996), Molecular cloning and sequence analysis of a cDNA encoding a cysteine proteinase inhibitor from Sorghum bicolor seedlings. Mol. Gen. Genet., 251 : (4), 499-502.

Liang, C.; Brookhart, G.; Feng, G. H.; Reeck, G. R. and Kramer, K. J. (1991), Inhibition of digestive profeinase of stored grain Coleoptera by oryzacystatin, a cysteine proteinase inhibitor from rice seed. FEBS Lett., 278 : (2), 139-142.

Machleidt, W.; Borchart, U.; Fritz, H.; Brzin, J.; Ritonja, A. and Turk, V. (1983), Protein inhibitors of cysteine proteinase II. Primary structure of stefin, a cytosolic inhibitor of cysteine proteinases for human polymorphonuclear granulocyles. Hoppe-Seyler's Physiol Chem., 364, 1481-1486.

Machleidt, W.; Thiele, U.; Laber, B.; ArsfaldMachleidt, I.; EsterL, A.; Wiegand, G.; Kos, J.; Turk, V. and Bode, W. (1989), Mechanism of inhibition of papain by chicken egg white cystatin: Inhibition constants of N-terminally truncated forms and cyanogen bromid fragments of the inhibitor. FEBS., 243 : (2), 234-238.

Matsumoto, I.; Watanabe, H.; Abe, K.; Arai, S. and Emori, Y. (1995), A putative digestive cysteine proteinase from Drosophila melanogaster in predominantly expressed in the embryonic and larval midgut. Eur. J. Biochem., 227, 582-587. 
Matsumoto, I.; Emori, Y.; Abe, K. and Arai, S. (1997), Characterization of a gene family encoding cysteine proteinases of Sitophilus zeamais (Maize weevil), and analysis of the protein distribution in various tissues including alimentary tract and germ cells. $J$. Biochem., 121, 464-476.

Michaud, D.; Cantin, L. and Vrain, T. C. (1995), Carboxyl-terminal truncation of oryzacystatin II by oryzacystatin insect digestive proteinases. Arch. Biochem Biphys., 322 : (2), 469-474.

Michaud, D.; Nguyen-Quoc, B.; Vrain, T. C.; Fong, D. and Yelle, S. (1996). Response of digestive proteinases from the Colorado potato beetle (Leptinotarsa decemlineata) and black vine weevil (Otiorynchus sulcatus) to a recombinant formof human stefin). Arch. Insect Biochem. Physiol., 31, 451-464.

Mikkonen, A.; Porali, I.; Ceros, M. and Ho, T. D. (1996), A major cysteine proteinase, EPB, in germinating barley seeds: structure of two intronless genes and regulation of expression. Plant Mol. Biol., 31, 239-254.

Misaka, T.; Kuroda, M.; Iwabuchi, K.; Abe, K. and Arai, S. (1996), Soyacystatin, a novel cysteine proteinase inhibitor in soybean, is distinct in protein structure and gene organization from other cystatins of animal and plan origin. Eur. J. Biochem., 240, 609-614.

Mitsuhashi, W.; Koshiba, T. and Minamikawa, T. (1986). Separation and characterization of two endopeptidases from cotyledons of germinating Vigna mungo seeds. Plant Physiol., 80, 628-634.

Murdock, L. L.; Brookehart, G.; Dunn, P. E.; Foard, D. E.; Kelly, S.; Kitch, L.; Shade, R. E.; Shuckle, R. H. and Wofson, J. L. (1987), Cysteine digestive proteinases in Coleoptera. Comp. Biochem. Physiol., 87 : (B), 783-787.

Murdock, L. L.; Shade, R. E. and Pomeroy, M. A. (1988), Effects of E-64, a cysteine proteinase inhibitor, on Cowpea weevil growth, developmente and fecundity. Environ. Entomol., 17. (3), 467-469.

Nakajima, Y.; Tsuji, Y.; Homma, K-I. and Naton, S. (1997), A novel protease in the pupal yellow body of Sarcophaga peregrina (flesh fly). The Jour. Biol. Chem., 272 : (38), 23805-23810.

Neurath, H. (1984), Evolution of Proteolytic Enzimes. Science., 224, 350-357.

Ojima, A.; Shiota, H.; Higashi, K.; Kamada, H.; Shimma, Yoh-Ichi Wadamasata and Satoh, S.(1997). An extracellular insoluble inhibitor of cysteine proteinases in cell cultures And seeds of carrot. Plant. Mol. Biol., 3,499-109.

Oliva, M. L. V.; Sampaio, M. U. and Sampaio, C. A. M. (1987), Serine- and SH-proteinase inhibitors from Enterolobium contorsiliquum Beans.Purification and preliminary charcterization. Brazilian J. Med. Res., 20, 767-770.
Oliveira, A. S. (2000), Purificação e caracterização de um inibidor de proteinase cisteínica de sementes de algaroba (Prosopis juliflora). Meinster thesis, Universidade Federal do Rio Grande do Norte, Natal/RN, Brazil.

Orr, G. L.; Strickland, J. A. and Walsh, T.A. (1994), Inhibition of Diabrotica larval growth by a multicystatin from potato tubers. J. Insect Physiol., 40 : (10), 893-900.

Pereira, R. A. (2000), Isolamento e caracterização parcial de uma proteinase serínica presente no intestino médio de larvas de Mimosestes mimosae (Coleoptera:Bruchidae). Meinster thesis, Universidade Federal do Rio Grande do Norte, Natal/RN, Brazil.

Pernas, M.; Sanchez-Monge, R.; Gomez, L. and Salcedo, G. (1998), A chestnut seed cystatin differentially effective against cysteine proteinases from closely related pests. Plant Mol. Biol., 38 : (6), 1235-1242.

Rawlings, N. D. and Barrett, A. J. (1994), Families of cysteine peptidases. Methods Enzymol., 244, 461-486.

Ryan, C. A. (1990). Protease inhibitors in plants: Genes for Improving Defenses gainst Insects and Pathogens. Annu. Rev. Phytopathol., 28425-429.

Ryan, S. N.; Liang, W. A. and McManus, M. T. (1998), A cysteine proteinase inhibitor purified from apple fruit. Phytochemistry., 49, 957-63.

Saitoh, F.; Isemura, S.; Sanada, K. and Ohnishi, K. (1991), Cystatins of family II are harboring two domains which retain inhibitory activities against the proteinase. Biol. Ciophys. Res. Commun., 175, 1070-1075.

Sato, N.; Ishidoh, K.; Uchiyama, Y. and Kominami, E. (1990), Molecular cloning and sequencing of cDNA for rat cystatin $\beta$. Nucleic Acids Res., 18 : (22), 6698.

Salmia, M. A. (1980), Inhibitors of endogenous proteinases in Scot pine seeds: fracionation and activity changes during germination. Physiol Plant., 48, 266-270.

Salvesen, G.; Parkes, C.; Abrahamson, M.; Grubb, A. and Barrett, A. J. (1986), Human low-Mr kininogen contain three copies of a cystatin sequence that are divergent in structure and in inhibitory activity for cysteine proteinases. Biochem. J., 234, 429-434.

Silva, C. P. and Xavier-Filho, J. (1991), Comparison between the levels of aspartic and cysteine proteinases of the larval midgut of Callosobruchus maculatus (F.) and Zabrotes subfascitus (Boh.) (Coleoptera:Bruchidae). Comp. Biochem. Physiol., 99 : (B), 529-533.

Schukle, R. H. and Murdock, L. L. (1983), Lipoxygenase, trypsin inhibitor, and lectin from soybeans: effects on larval growth of Manduca Sexta (Lepidoptera : Sphigidae). Environ. Ent., 12, 787-791. 
Solommon, M.; Belenghi, B.; Delledonne, M.; Menachen, E. and Levine, A. (1999), The involvement of cysteine proteinase and protease inhibitor genes in the regulation of programmed cell death in plants. The Plant Cell.,11, 431-443.

Stubbs, M. T.; Laber, B.; Bode, W.; Huber, R.; Jerala, R.; Lenarcic, B. and Turk, V. (1990), The refined $2.4 \mathrm{~A}$ X-ray crystal structure of recombinant human stefin $\mathrm{B}$ in complex with the cysteine proteinase papain: a novel type of proteinase inhibitor interaction. EMBO J., 9, 1939-1947.

Steller, H. (1995), Mechanisms and genes of cellular suicide. Science., 267, 1445-1449.

Takahashi, N.; Kurata, S. and Natori, S.(1993), Molecular cloning of cNDA for the $29 \mathrm{kDa}$ proteinase participating in decomposition of the larval fat body during metamorphosis of Sarcophaga peregrina (flesh fly). FEBS Lett., 334, 153-157.

Tanaka, T.; Yamauchi, D. and Minamikawa, T. (1991), Nucleotide sequence of cDNA for an endopeptidase (EP-C1) from pods of maturing Phaseolus vulgaris fruits. Plant Mol. Biol., 161083-1084.

Tanaka, T.; Minamikawa, T.; Yamauchi, D. and Ogushi, Y. (1993), Expression of an endopeptidase (EP-C1) in Phaseolus vulgaris plant. Plant Physiol., 101, 421-428.

Thie, N. M. R. and Houseman, J. G. (1990), Identification of cathepsin B, D and $\mathrm{H}$ in the larval midgut of Colorado potato beetle Leptinotarsa decemlineata. Insect Biochem. 20313-318.

Trysellius, Y. and Hultmark, D. (1997), Cysteine proteinase 1 (CP1), a chatepsin L-like enzyme expressed in the Drosophila melanogaster haemocyte cell line mbn-2. Insect Mol. Biol., 6 : (2),173-181.

Turk, V. and Bode, W.(1991), The cystatins: proteinase inhibitors of cysteine proteinases. FEBS Lett., 285 , 213-219.

Turk, B.; Turk, V. and Turk, D. (1997), Structural and functional aspects of papain-like cysteine proteinases and their protein inhibitors. Biol. Chem. Hopp Seyler., 378,141-150.

Urwin, P. E.; Atkinson, H. J.; Waller, D. A. and McPherson, M. J (1995), Engineered oryzacystatin-I expressed in transgenic hairy roots confers resistance to Globodera pallida. Plant. J., 8 : (1), 121-131.

Urwin, P. E.; Lilley, C. J.; McPherson, M. J. and Atkinson, H. J. (1997), Resistance to both cyst and root-knot nematodes confered by transgenic Arabidopsis expressing a modified plant cystatin. Plant. J., 12 :(2), 455-61.

Waldron, C.; Lynett, M.; Wegrich, P.; Merlo, A. O. and Walsh, T. A. (1993), Characterization of a genomic sequence coding for potato multicystatin, an eightdomain cysteine proteinase inhibitor. Plant Mol. Biol., 23, 801-812.
Walsh, T. A. and Strickland, J. A. (1993), Proteolysis of the 85-Kilodalton crystalline cysteine proteinase inhibitor from potato release functional cystatin domains. Plant Physiol., 103 : (4), 1227-1234.

Wolfson, J. L. and Murdock, L. L. (1987), Suppression of larval Colorado potato beetle growth and development by digestive proteinase inhibitors. Entomol. Exp. Appl., $\mathbf{4 , 4 2 3 5 . ~}$

Watanabe, H.; Abe, K.; Emori, Y.; Hosoyama, H. and Arai, S. (1991), Molecular cloning and gibberellininduced expression of multiple cysteine protease of rice seeds (orizains). J. Biol. Chem., 266, 16897-16902.

Wieman, K. F. and Nielsen, S. S. (1988), Isolation and partial characterization of a major gut proteinases fromlarval Acanthoscelides obtectus Say (Coleoptera, Bruchidae). Comp Biochem Physiol., 89B : (2), 419-426.

Xavier-Filho, J. and Coelho, A. N. (1980), Acid proteinases of Callosobruchus maculatus and proteinase inhibitors of Vigna unguiculata. Abstract from the Annual Meeting of the American Soc. Plant Physiol. And Phytochemical Society of North America. Plant Physiol., 65, 138.

Yamamoto, Y.; Takimoto, K.; Izumi, S.; ToriyamaSakurai, M.; Kageyama, T. and Takahashi, S. Y. (1994), Molecular cloning and sequencing of cDNA that encodes cysteine proteinase in the eggs of the silkmoth, Bombys mori, J. Biochem., 116, 1330-1335.

Zhao, Y.; Botella, M. A.; Subramanian, L.; Niu, X.; Nielson, S. S.; Bressan, R. A and Hasegawa, P. M. (1996), Two wound inducible Soybean cystein proteinase inhibitors have greater insect digestive proteinase inhibitory activities then a constitutive homolog. Plant Physiol., 111, 1299-1306.

Received: May 07, 2001;

Revised: June 26, 2001; Accepted: November 05, 2001. 